\title{
Work Discipline and Work Competence with Quality of Service in the Office of Religious Affairs (KUA) District of Mount Kencana Lebak Regency of Banten
}

\author{
Itang $^{1}$ \\ ${ }^{1}$ Lecturer of IAIN Sultan Maulana Hasanuddin, Serang, Banten, Indonesia \\ Correspondence: Itang, Lecturer of IAIN Sultan Maulana Hasanuddin, Serang, Banten, Indonesia. E-mail: \\ itang.103@gmail.com
}

Received: April 18, 2015 Accepted: May 25, 2015 Online Published: August 28, 2015

doi:10.5539/jms.v5n3p132ＵRL: http://dx.doi.org/10.5539/jms.v5n3p132

\begin{abstract}
This study was conducted to determine and analyze the influence of labor discipline and competence of employees working for the quality of service in the office of religious affairs. This research was conducted by using a quantitative approach through descriptive methods, correlation and multiple regression analysis. Samples were communities around the Office of Religious Affairs (KUA) District of Mount Kencana Banten Lebak district and 160 respondents were sampled in the study. Likert scale was used in the data collection. The results showed that employee discipline, employee competence and quality of service have good grades. Employee discipline as well as employee competence has an influence on the quality of service. It can be concluded that the quality of service in the Office of Religious Affairs (KUA) can be enhanced through the development and improvement of work discipline and employee competence. It takes a real effort to maintain and improve the discipline and competence of employees working continuously.
\end{abstract}

Keywords: work discipline, employee competence, quality of service

\section{Introduction}

Service is an activity, product, service that intangible that can not be owned, not durable, but experienced and perceived by the service recipient. One factor is the low quality of service. Service quality is said or satisfactory if the service can meet the needs and expectations of society. As government agencies that deal with the public, Religious Affairs Office requires the provision of a quality service to the community to be one of the obligations that must be done. In the implementation of the community service of fact receiving services exceeding expectations, the customer would say the quality of service. Public services by government officials still have weaknesses and shortcomings. They are characterized by the presence of various public complaints submitted through the mass media, which can result in unfavorable image of the government apparatus (Rofiatun \& Masluri, 2011).

To improve the quality of service requires human resources having the discipline and high work competence. The discipline reflects a person's sense of responsibility towards the tasks assigned to him. This encourages morale and the realization of organizational goals. Discipline must be enforced in an organization because without good personnel discipline, it would be difficult to realize the organization's purpose. Hasibuan (1996) promoted that, good discipline reflects a person's responsibility for the tasks assigned to him. This will encourage passion or morale and promote the organization's goals.

According to Buhler (2007), discipline actually played an important role in shaping behavior. As well as the award is effective in motivating people, disciplined if used properly. It can be equally effective. Along with the increase in disputes in the workplace today, you should make sure that you are careful to observe the discipline. Tohardi (2002), said the indiscipline of individuals or employees can affect the productivity of the organization. Thus employees must have discipline if want to enhance the work. When serve the public, the Office of Religious Affairs (KUA) employees provide the best service, which requires an employee' qualities. This increase is through the cultivation of self-discipline in the works as well as an increase in job competency.

Employee competence is defined as work procedures performed by the employee to achieve maximum work and satisfy the necessary competencies possessed by an employee in carrying out his duties. Organization will thrive 
and be able to survive in a competitive environment where competition is supported by competent personnel in the field. The purpose of this study is to determine and analyze the effect of work discipline and competence of employees working on improving quality of service in the Office of Religious Affairs (KUA) District of Mount Kencana Lebak regency, Banten.

\section{Literature Review}

\subsection{Work Discipline}

Pidarta (1987) argued that the discipline is an appropriate work procedure and rules have been agreed. Lateiner (1995), said that the discipline is a growing force in the body or self-employed, and that causes a person to be able to adapt to the voluntary decisions, and regulations in the high values of work and behavior.

Rival (2004), stated that discipline is a tool that managers use to change a behavior as well as an effort to boost awareness and a willingness to obey all the rules of corporate and social norms that apply. While Singodimedjo (2002), said discipline is an attitude of readiness and willingness to adhere to and comply with regulatory norms prevailing around him. Good employee discipline will accelerate the company's objectives. Discipline deteriorated would be prohibitive and slow the achievement of corporate goals. Similarly, Fathoni (2006) argued discipline is an awareness and willingness to comply with all company rules and social norms that apply. Discipline that an employee owns shows the characteristics and personality of an employee. An employee who has a high work discipline has awareness and desire to perform all the duties and responsibilities with the willingness to comply with all applicable laws in an institution or organization.

Discipline is a growing force in the body that causes the worker himself. He can adjust to volunteer to decisions, regulations, and high values of work and behavior (Asmiarsih, 2006). Davis and Newstrom (1989) suggested in disciplining teachers there are three characteristics that can be implemented, namely: Discipline prevention (preventive dicipline) are actions taken to encourage teachers to follow the standards and regulations, so there is no infringement. The main objective is to encourage the emergence of self-discipline among teachers. Discipline repair (corrective dicipline) is an action taken to address violations of the rules. The goal is to correct and educate in order to avoid further violations among other teachers. Corrective action is a form of punishment or disciplinary action. Progressive discipline is a disciplinary action which is becoming increasingly severe punishment every time the offense.

Beach in Siagian, (2002), said that the discipline has two meanings; the first meaning, involves learning or behavioral scoring by applying a reward or punishment. The second meaning is more narrowly, that is only related discipline with punitive action against the wrongdoer.

Nitisemito (2001) wrote that the discipline is also defined a trait, behavior and act in accordance with the rules of an organization, whether written or not. Sastrohadiwiryo (2002) argued, labor discipline as a trait honor, respect, obey and adhere to the regulations in force, whether written or unwritten, to be able to run it and not avoid to receive his sentence. He broke his duties and power was given to him. Their discipline, then the employees will comply with all regulations as there are so implementation can work in accordance with a predetermined plan.

According to Mangkunegara (2001), suggested that there are two forms of discipline, namely: Preventive discipline is an attempt to move the employee to follow and adhere to the guidelines. Rules have been outlined by the company. Corrective discipline is an effort to mobilize officers in consolidating a rule and ordered to remain in compliance with the regulations in accordance with the guidelines in force at the company.

There are several indicators that affect labor discipline as expressed by Hasibuan (2006) said that basically many indicators that affect the level of employee discipline in an organization, including: 1. Leadership purposes, 2. Exemplary leaders. 3. The remuneration. 4. Justice. 5. Supervision attached. 6. Sanctions punishment. 7. The firmness. 8 . The relationship of humanity.

Tu'u (2004) suggested some disciplinary functions include managing life together, building a personality, personality training, coercion, punishment, creating. Hasan (2002) formulated indicators of labor discipline are as follows: 1) Implement and complete the task on time, 2) Working with the full creative and initiative, 3) Working with honesty, passion and responsibility, 4). Come and go home on time. 5) Acting polite behavior.

Rival (2004) stated that there are four perspectives concerning the list of work discipline, namely: Retributive Discipline, which seeks to punish those who do wrong; Corrective Discipline, which seeks to help employees correct improper behavior; The perspective of individual rights (Individual Rights perspective), which seeks to protect the fundamental rights of the individual over disciplinary actions; Utilitarian Perspective, which focuses on the use of discipline only when the consequences of disciplinary action exceeds adverse effects. 


\subsection{Competence Employee Work}

In the Law of the Republic of Indonesia No. 13 of 2003, on employment, states that competence is the ability of each individual work that includes aspects of knowledge, skills, and attitudes that work in accordance with established standards. Competence is the ability to execute or perform a job or task that is based on the skills and knowledge and is supported by the work attitude demanded by the job (Wibowo, 2007).

Malthis and Jackson (2006) said that competence is the basic characteristics that can be attributed to the improved performance of individuals or teams. Dessler (2006) defines competence as a characteristic of a person who can be shown, which includes knowledge, skills, and behaviors, which can result in performance and achievement. Competency of individuals can support the work system based team (Rivai, 2009). Spencer and Spencer in Palan (2007), argued that competence refers to the characteristics that describe the behavior of the underlying motives, personal characteristics (typical), self-concept, values, knowledge or expertise that brought someone superior performance in the workplace.

According to Dharma (2005) competency always have the intent or purpose, which is a trait of motives or causes an action to obtain a result that the performance of the employee. Nick Boreham (2004), said contempory work-related education and training is the policy of job competence as a result of the performance of individuals in the workplace. This work presents a critique of neo-liberal assumptions, arguing that in many cases the competence must be planned as an attribute groups, teams, and communities. It proposes a theory of collective competence in terms of (1) create a sense of collective events in the workplace, (2) develop and use the collective knowledge base and (3) develop a sense of interdependence.

Prihadi (2004), said that the main component of competence is a set of knowledge, skills, and attitudes are interrelated affect most positions (roles or responsibilities), correlated with performance on the job, and can be measured by standards that are acceptable, and can be improved through the efforts of training and development. Hutapea and Thoha (2008) revealed that there are four main components, namely the establishment of competence requiring knowledge, ability, experience, and behavior of individuals.

Sutrisno (2011) explained that the notion of competence in public and private organizations is needed, especially to answer the demands of the organization. The changes are very rapid. Development issues are very complex and dynamic and uncertain future in the order of a society. Danim (2008) defined competence as a set of knowledge and skills. Basic values are reflected in the habit of thinking and acting. Spencer and Spencer in Palan, (2007), outlined the five characteristics that make up the competence, namely 1) Knowledge; refer to the information and learning outcomes. 2) Skills; refers to a person's ability to perform an activity. 3) The concept of self and values; refers to the attitudes, values and self-image, such as a person's belief that he could succeed in a situation. 4). Personal characteristics; refers to the physical characteristics and consistency of responses to situations or information, such as self-control and ability to remain calm under pressure. 5) Motif; the emotions, desires, needs psychological or other impulses that trigger the action.

\subsection{Quality of Service}

According Heizer and Render in Wibowo (2007), quality as the ability of a product or service meets customer needs. Quality is a combined overall characteristic of the product or service being used to meet customer expectations (Feigenbaum, 1989). Quality is the number of attributes or properties as described in the product (goods and services) in question include durability, comfort, efficiency and so on (Ahyari, 1990).

Service is any activity that is beneficial in a unified collection, and offers a satisfaction although the results are not tied to a physical product (Sinambela, 2006). According to Sinambela et al. (2011) theoretically, the purpose of public service is basically to satisfy the community. Atmaja (2002) in his research argued that the public service can be defined as the provision of services (airport) for a person or people who have an interest in the organization in accordance with the basic rules and procedures that have been set.

Public service is a means serving the interests of the general public in a country. Public service means providing services for a general public in a country (The Liang Gie, 1997). Armstrong (1996) stated that the company providing high quality services typically performs much better than stated competitors who are less service-oriented. It can be said that the achievement of an institution or organization is located on the service provided; especially in the Office of Religious Affairs, quality service delivery showed high achievement.

Moenir (1998) noted that public services in general coveted namely: (1) the ease in handling the interests of the fast service. (2) obtaining services without satirical tone naturally leading to demand something, either official or for welfare reasons. (3) receiving the same treatment in the service of the same interests. (4) honest and forthright service. 
Lovelock in Widodo (2001), argued that the five principles should be considered for public servants, so that the quality of service can be achieved include: Firstly, Tangible, such as physical abilities, equipment, personnel, and communication materials. Secondly, reliable, the ability to form proper care and promised to have regularity. Thirdly, responsiveness, the sense of responsibility for the quality of service. Fourthly, assurance, namely knowledge, behavior and abilities of employees. Fifthly, empathy, the individual's attention on the customer.

\section{Research Methods}

This descriptive study applied a quantitative approach. Descriptive study data are usually collected by administering questionnaires, interviewing respondents, observing events or analyzing documents (Dalen, 1979). According to Mohd. Majid (1990), quantitative variables are associated with a phenomenon without questioning why the variable exists. Kerlinger (2000) said "The most appropriate method for the quantitative survey was used to examine the relationships between variables". Quantitative research uses product moment correlation analysis and multiple regression. Correlation study, "aims to detect the extent to which variations in the factors associated with variations in one or more other factors, based on the correlation coefficient" (Suryabrata, 1992). Prior to the correlation and regression test beforehand to test. This is due to the correlation calculation requires that the population from which the sample has two variance and normal distribution (Santoso, 2002a). In this model, there is a dependent variable and independent variables (Santoso, 2002b). The equation is useful for predicting or forecasting how far the influence of a variable or several independent variables variable depending (Pratisto, 2009).

Samples were taken from people who were in the vicinity of the Religious Affairs Office (KUA). This is becuase the surrounding communities of Religious Affairs Office (KUA) feel and know clearly how services provided in various activities related to community needs with particular regard to religious. The research sample contains 160 people; sampling according to Sekaran (2003), the number of samples between 30-500 respondents is sufficient to study the case.

The instrument used in this study was a questionnaire (questionnaire) which are arranged according to a Likert scale mode. 5 points Likert scale used to indicate the level of frequency that things happen and vice versa for each statement submitted (Cavanagh, 2005). According to Suarny Lily (2003), instruments of labor discipline used namely: (1) complying with the rules of 5 items, (2) awareness of their duties (3) self reformation, (4) discipline, (5) high expectations and (6) motivation in the discipline. Spencer and Spencer in Palan, (2007), described five characteristics that constitute competence, namely 1) knowledge, 2) skills, 3) self-concept and values, 4) Personal characteristics and 5) motif. For service quality instruments of Lovelock in Widodo, (2001), there are five principles of public servants, including tangible, reliable, responsiveness, assurance, empathy.

\section{Research}

\subsection{Descriptive Analysis}

Descriptive data, in this study includes the mean and standard deviation of the three variables of the study. The raw data were processed using descriptive statistical methods. More descriptive statistical methods associated with collecting and summarizing the data, as well as the presentation of the summary data. Descriptive research results can be seen in table 1 below:

Table 1. Descriptive statistics of quality of service, work discipline, work competence

\begin{tabular}{|c|c|c|c|c|c|c|}
\hline No & Variable & \multicolumn{2}{|c|}{ Dimention } & Mean & Standard Deviation & Interpretation \\
\hline \multirow[t]{5}{*}{1} & Quality of Service & 1) & Tangible & 21.41 & 1.785 & High \\
\hline & & 2) & Reliable & 20.62 & 1.939 & \\
\hline & & 3) & Responsiveness & 20.97 & 1.831 & \\
\hline & & 4) & Assurance & 21.44 & 1.516 & \\
\hline & & 5) & Empathy & 19.41 & 2.526 & \\
\hline \multirow[t]{6}{*}{2} & Work discipline & 1) & Complying with the rules & 22.24 & 2.336 & High \\
\hline & & 2) & Awareness of duty & 22.99 & 2.593 & \\
\hline & & 3) & Self-examination & 22.90 & 2.486 & \\
\hline & & 4) & Enforce discipline. & 19.86 & 2.005 & \\
\hline & & 5) & High Expectations & 20.35 & 2.013 & \\
\hline & & $6)$ & Motivation in the discipline & 20.62 & 2.082 & \\
\hline \multirow[t]{5}{*}{3} & Work competence & 1) & Knowledge & 20.78 & 2.074 & High \\
\hline & & 2) & Skills & 19.56 & 2.990 & \\
\hline & & 3) & The concept of self and values & 20.21 & 2.233 & \\
\hline & & 4) & Personal characteristics & 20.51 & 2.525 & \\
\hline & & $5)$ & Motif & 19.77 & 2.695 & \\
\hline
\end{tabular}


In Table 1, it is seen that the overall quality of service shown by the respondents have a high value, for tangible dimensions of service quality variables $($ mean $=21.41, \mathrm{SD}=1.785)$, reliable $($ mean $=20.62, \mathrm{SD}=1.939)$, responsiveness $($ mean $=20.97, \mathrm{SD}=1.831)$, assurance $($ mean $=21.44, \mathrm{SD}=1.516)$, empathy $($ mean $=19.41, \mathrm{SD}$ $=2.526)$. Variable employee discipline on the dimensions of regulations (mean $=22.24, \mathrm{SD}=2.336)$, awareness of duty $($ mean $=22.99, \mathrm{SD}=2.593)$, the dimensions of introspection $($ mean $=22.90, \mathrm{SD}=2.486)$, discipline $($ mean $=19.86, \mathrm{SD}=2.005)$, expectations were high $($ mean $=20.35, \mathrm{SD}=2.013)$, motivation in the discipline $($ mean $=20.62, \mathrm{SD}=2.082)$. Job competence variable has a high value, it can be seen from the value of the knowledge dimension $($ mean $=20.78, \mathrm{SD}=2.074)$, skills $($ mean $=19.56, \mathrm{SD}=2.990)$, the concept of self and values $($ mean $=20.21, \mathrm{SD}=2.233)$, personal characteristics $($ mean $=20.51, \mathrm{SD}=2.525)$, dimensional motif $($ mean $=19.77, \mathrm{SD}=2.695)$. The formulation of the above results shows that the dimensions of each variable have a high interpretation.

\subsection{Correlation Analysis}

To see the relationship between variables, using about the instrument (questionnaire) were answered by 160 people, through Pearson correlation analysis. The correlation analysis Provides Pearson correlation coefficient $r$ the same shape there is a positive $(+)$ or negative $(-)$ to indicate a form of interaction between variables. Coefficient values between 0:00 to $1: 00$ also shows the strength of the relationship. Value 'rule of thumb' by Johnson and Nelson (1986) is used to describe the strength of the correlation was no correlation (0.00); very low; low; simple; very high and perfect relationship (1.00).

\subsubsection{Influence of Employee Work Discipline on the Quality of Service}

The effect of employee discipline to quality of service seen in Table 2, from the table shows that the variable employee discipline to quality of service has value relationship $(r=0.197)$ shows the relationship as a whole discipline of employees working on service quality significantly. There was no relationship between several dimensions of employee discipline with variable dimensions of quality of service. Looks at the dimensions obey the rules do not have a significant relationship to the tangible dimension, the dimension reliable, assurance, and empathy, as well as to the variable quality of service. Dimensions obey the rules have a significant relationship to dimensions of responsiveness $(\mathrm{r}=0.230)$. The dimensions of consciousness perform tasks have not a significant relationship to the dimensions of responsiveness, assurance dimension, the dimension of empathy. Dimensional awareness tasks has a significant relationship to the tangible dimension $(\mathrm{r}=0.223)$, with dimensions reliable $(r=0.227)$ as well as to quality of service $(r=0.260)$. Dimensions of self introspection, dimensions and dimensional discipline high expectations do not have a significant relationship to the entire dimension of service quality variables.

Dimensions of motivation in the discipline do not have a significant relationship to dimensions of responsiveness, assurance dimension, the dimension of the variable quality of empathy and service. Dimensions of motivation in the discipline has a significant relationship to the tangible dimension $(r=0.181)$, with dimensions reliable $(r=$ 0.169). Variable employee discipline has no significant relationship to the dimensions of responsiveness, assurance dimension and empathy dimensions. Variable employee discipline has a significant relationship to the tangible dimension $(r=0.219)$, the dimensions of reliable $(r=0.186)$ as well as to the variable quality of service $(r=0.197)$. Adaptive research on the relationship between the discipline of employees and the quality of service can be seen in Table 2, namely:

Table 2. Effect of employee work discipline on quality of service

\begin{tabular}{|c|c|c|c|c|c|c|}
\hline $\begin{array}{l}\text { Quality of Service } \\
\text { Work Discipline }\end{array}$ & Tangible & Reliable & Responsiveness & Assurance & Empaty & Quality of Service \\
\hline Complying with regulations & 0.133 & -0.046 & $0.230 * *$ & -0.004 & -0.019 & 0.110 \\
\hline Awareness tasks & $0.223 * *$ & $0.227 * *$ & 0.068 & 0.038 & 0.076 & $0.260 * *$ \\
\hline self-intropection & 0.042 & 0.129 & -0.150 & 0.027 & -0.047 & -0.006 \\
\hline enforcing discipline & -0.133 & -0.054 & -0.005 & -0.046 & -0.040 & -0.112 \\
\hline High expectations & 0.119 & 0.047 & 0.051 & -0.055 & 0.126 & 0.136 \\
\hline Employee discipline & $0.219 * *$ & $0.186^{*}$ & 0.082 & 0.024 & -0.007 & $0.197 *$ \\
\hline
\end{tabular}

* significant in the direction of $\mathrm{p}<0.05$. 


\subsubsection{Influence of Employee Work Competence on Quality of Service}

The effect of employee competence to quality of service seen in Table 3, the variable employee competence have been associated with quality of service $(r=0.251)$, which indicates that the quality of service can be affected by the employee competence. There is a significant relationship between the dimensions of skills to reliably dimension $(\mathrm{r}=0.173)$, the dimensions of self-concept and value of the dimension reliable $(\mathrm{r}=0.162)$, as well as to the variable quality of service $(r=0.155)$. Dimensional motif has a significant relationship to the dimension of assurance $(r=0.190)$ and to the variable quality of service $(0.219)$. Job competence variables have a significant relationship to reliably dimension $(\mathrm{r}=0.176)$, as well as to the variable quality of service $(\mathrm{r}=0.251)$. The dimensions of knowledge and personal characteristics of the dimensions have a weak correlation to the overall dimensions of quality of service. Dimensions skills have a weak connection to the tangible dimension, responsiveness, assurance, empathy and quality of service. Dimensions of self-concept and value have a weak connection to the tangible dimension, responsiveness, assurance and empathy dimensions. Dimensional motif has a weak relationship to the tangible dimension, reliable, responsiveness and empathy dimensions. Adaptive research on the relationship between employee competence and the quality of service can be seen in Table 3 , namely:

Table 3. Effect of employee competence on the quality of service

\begin{tabular}{lllllll}
\hline \multicolumn{1}{c}{ Quality of Service } & Tangible & Reliable & Responsiveness & Assurance & Empaty & Quality of Service \\
\cline { 1 - 3 } Work competence & & & & & & \\
\cline { 1 - 5 } knowledge & 0.034 & 0.012 & 0.068 & -0.041 & -0.115 & -0.31 \\
skills & 0.071 & $0.173^{*}$ & 0.070 & 0.024 & 0.024 & 0.147 \\
Self-concept and value & 0.082 & $0.162^{*}$ & 0.015 & 0.050 & 0.062 & $0.155^{*}$ \\
personal characteristics & 0.087 & -0.036 & 0.130 & -0.021 & 0.139 & 0.138 \\
Motif & 0.101 & 0.130 & 0.065 & $0.190^{*}$ & 0.071 & $0.219^{*}$ \\
Work competence & 0.144 & $0.176^{*}$ & 0.134 & 0.084 & 0.078 & $0.251^{*}$ \\
\hline
\end{tabular}

* significant in the direction of $\mathrm{p}<0.05$.

\subsubsection{Influence of Employee Work Discipline and Competence Employee Work Together on Quality of Service}

The question is whether there is significant influence further of employee discipline and competence working together on quality of service. Multiple regression analysis is used to indicate the index of interaction that is, with reference to the value of the beta $(\beta)$, which can be seen in Table 4.

Table 4. Effect of employee work discipline and employee work competence together against quality of service

\begin{tabular}{lllll}
\hline Variable & B & Beta $(\beta)$ & Value T & Sig \\
\hline Constant & 64.476 & & 6.878 & 0.000 \\
Work Discipline & 0.161 & 0.212 & 2.809 & 0.006 \\
Work Competence & 0.185 & 0.262 & 3.476 & 0.001 \\
\hline
\end{tabular}

* significant in the direction of $\mathrm{p}<0.05 . \mathrm{r}=0.328, \mathrm{R}^{2}=0.108$.

Multiple regression analysis is done through Table 4. From the table above, variable labor discipline has influence on the quality of service at a significant level $p<0.05$. Beta $(\beta)$ between discipline and service quality is $(\beta=0.212 ; \mathrm{t}=2.809 ; \mathrm{Sig}=0.006)$. It can be said that the discipline of employee acts as a cause or a fortune teller to improve the quality of service. Low or high quality of service can be affected by the work discipline. Competence has a relationship with the quality of service at a significant level $p<0.05$. Beta ( $\beta$ ) between employee competence and the quality of services is $(\beta=0.262 ; \mathrm{t}=3.476 ; \mathrm{Sig}=0.001)$. Thus it can be seen that the employee competence is a cause or a fortune teller to the low or the high quality of service.

\section{Discussion}

The survey results revealed that the descriptive variables employee discipline, employee competence and quality of service have a high value. Demonstrated a high work discipline employees in the execution of their tasks and responsibilities give you change the public's assessment of the quality of the staff in the office of religious affairs. Each institution especially government agencies want the improvement of discipline on each employee. This is not the maximum of service and achievement of the goals of the institution. Mathis dan Jackson (2002), effective 
discipline should be directed at the behavior and not to the employee or the employee personally, because the reason for the discipline is to improve the performance of an employee.

In addition to employee discipline other factors that influence by the quality of service in the Office of Religious Affairs (KUA) is employee competence. An employee who does not have a good competence may give a bad influence on the quality of service, job competence is very important to be owned by employees. This is due to the absence of a good job competence employees will not have a good performance. Also added by Moeheriono (2009) A man in order to get high performance to the maximum individual competencies possessed supposed to be fit or match the competency to bear, this will result in a match with its capabilities

According Palan (2007), the organization will benefit through a competent workforce. In the face of environmental influences organizational. Human resource readiness requires organizations to have the ability to answer this challenge by demonstrating its performance through activities in the field of tasks and work in the organization (Sutrisno, 2011).

Competence of work an employee, the employee representing quality self, an employee who has competence would work well too. Ruky (2006) said that competence is a basic characteristic of a person (an individual) that affect the way of thinking and acting, to generalize to all situations faced and survived long enough in humans. Office of Religious Affairs (KUA) can be high achievers when people who work in the office of Religious Affairs (KUA) can make the maximum contribution to the institution in accordance with the duties and abilities.

Quality of service in the Office of Religious Affairs (KUA) is influenced by the discipline of employee and employee competence; it is seen from the results of research that has been done. can be said that the quality of service in the Office of Religious Affairs (KUA) has a high value if the increase in employee discipline and competence possessed employees working in the Office of Religious Affairs (KUA).

Sedarmayanti (2004) stated that the human resources that have high competence strongly support the organization to move forward and thrive. To produce the best quality of service the employee in the performance of duties and responsibilities to work more professional so as to meet the desires and expectations of society as users of services of Religious Affairs Office (KUA). Sedarmayanti (2004) said that the success or failure of an organization in reaching their goals in sustainability relies heavily on human resources.

\section{Conclusion}

Improving the quality of service in the Office of Religious Affairs (KUA) can be done by increasing employee discipline and employee competence. Therefore, organizations need to make efforts on acquisition or development of competencies systematically. Competence development can be done with coaching and capacity building and motivation owned. Employees become a key determinant in the success of an organization, including the Office of Religious Affairs (KUA). In improving the success of the organization, employees should be able to improve the mastery of knowledge related to the job. Experience is a good teacher, and makes the employees always reflect that what happens at this point that may be a relation of issues ago. The employee must be able to demonstrate a consistent effort in carrying out all duties and responsibilities.

Employees who lack discipline will be difficult to increase the professionalism of the work so as to degrade the quality of service in the Office of Religious Affairs (KUA). Employee discipline complying with all the norms and regulations of the organization or agency will be able to improve the efficiency, effectiveness and productivity. Increasing discipline requires leadership role in the enforcement, which can be achieved with custom-positive habits carried out continuously and with the help and policies related to human resource development. Without a strategy and implementation activities related to discipline the employee may not have a good discipline in the organization.

In addition to working discipline, another factor that affects the quality of service is working competence. Competence is needed in an organization, including the Office of Religious Affairs (KUA). It should be a continuing education and training, aiming to increase the competency of employees of the Office of Religious Affairs (KUA). Improving the quality of employees can improve the quality of the organization.

\section{References}

Ahyari, A. (1990). Manajemen Produksi, Pengendalian Produksi. Yogyakarta: BPFE.

Arikunto, S. (1993). Prosedur Penelitian, Suatu Pendekatan Praktek. Edisi Kesembilan, Jakarta: Rineka Cipta.

Armstrong. (1996). Effective Teaching in Elementary Social Studies. New Jersey: Prentice Hall, Inc.

Asmiarsih, T. (2006). Pengaruh Pengawasan Terhadap Disiplin Kerja Pegawai Kantor Badan Kepegawaian Daerah Brebes. Fakultas Ilmu Sosial Universitas Semarang. 
Atmaja, A. K. (2002). Kualitas Pelayanan Publik di Unit Pelayanan Terpadu (UPT) Kabupaten Jember. Tesis. Universitas Gajah Mada.

Boreham, N. (2004). A theory of collective competence challenging the ne-liberal individualisation of Performance at work. Journal of Management Development, 27(1), 5-7.

Buhler, P. (2007). Management Skill. Jakarta: Alpha Teach Yourself.

Cavanagh, A. L. (2005). Introduction to Principalship.In J. Shen (Ed.), School Principals. New York: Peter Lang Publishing. Inc.

Dalen, Van, D. B. (1979). Understanding Educational Research An Introduction. New York: Mc Grow-Hill, Inc.

dan Masluri, R. (2011). Pengaruh Iklim Organisasi Dan Kompetensi Pegawai Terhadap Kinerja Pegawai Dengan Mediasi Motivasi pada Dinas-Dinas Di Kabupaten Kudus. Jurnal Analisis Manajemen, 5(1).

Danim, S. (2008). Kinerja Staf dan Organisasi. Cetakan ke-1. Jakarta : CV. Pustaka Setia.

Davis, K., \& Newstrom, J. W. (1989). Human Behavior at Work Organizational. New York: Graw Hill Book Company.

Dessler, G. (2006). Manajemen Sumber Daya Manusia Jilid 1. Jakarta: PT. Indeks.

Dharma, S. (2005). Manajemen Kinerja; Falsafah Teori dan Penerapannya. Yogyakarta: Pustaka Pelajar.

Fathoni, A. (2006). Organisasi dan Manajemen Sumber Daya Manusia. Jakarta: Rineka Cipta.

Feigenbaum, A. V. (1989). Kendali Mutu Terpadu. Jakarta: Penerbit Erlangga.

Hasan, D. (2002). Kemampuan Manajerial Pimpinan dalam Memotivasi dan Mendisiplinkan Karyawan dikaitkan dengan Produktivitas Kerja. Bandung: PPs UPI.

Hasibuan, M. (1996). Organisasi dan Motivasi \& Dasar-Dasar Peningkatan Produktivitas. Jakarta: Bumi Aksara.

Hasibuan, M. S.P. (2006). Manajemen Sumber Daya Manusia (Edisi Revisi). Jakarta: Bumi Aksara.

Hutapea, P., \& Thoha, N. (2008). Kompetensi Plus: Teori, Desain, Kasus dan Penerapan untuk HR dan Organisasi yang Dinamis. Jakarta: Gramedia Pustaka Utama.

Johnson, B. L., \& Nelson, J. K. (1986). Practical Measurement for Evaluation in Physical Education. New York: McMillan Publishing Company.

Kerlinger, F. N. (2000). Foundation of Behavioral Research. USA: Holt, Reinnar \& Winston, Inc.

Konting, M. M. (1990). Kaedah penyelidikan pendidikan. Kuala Lumpur: Dewan Bahasa \& Pustaka.

Lateiner, A. R. (1995). Teknik Memimpin Pegawai dan Pekerja (Terjemahan Imam Soedjono). Jakarta: Aksara Baru.

Mangkunegara, A. P. (2001). Manajemen Sumber Daya Manusia Perusahaan. Bandung: PT Remaja Rosda Karya.

Mathis, R. L., \& dan Jackson, J. H. (2002). Human Resoursce Management. Alih Bahasa. Jakarta: Salemba Empat.

Mathis, R. L., \& dan Jackson, J. H. (2006). Manajemen Sumber Daya Manusia. Diterjemahkan oleh Jimmy Sadeli dan Bayu Prawira Hie, Edisi kelima, Jakarta: Salemba Empat.

Moeheriono. (2009). Pengukuran Kinerja Berbasis Kompetensi. Bogor: Ghalia Indonesia

Moenir. (1998). Manajemen Pelayanan Umum di Indonesia. Jakarta: Bumi Aksara.

Nitisemito, A. S. (2001). Manajemen Personalia. Jakarta: Ghalia Indonesia.

Palan, R. (2007). Competency Management: Teknis Mengimplementasikan Manajemen SDM Berbasis Kompetensi untuk Meningkatkan Daya Saing Organisasi. Jakarta: PPM.

Pidarta, M. (1987). Peranan Kepala Sekolah pada Pendidikan Dasar. Jakarta: PT Gramedia.

Pratisto, A. (2009). Statistik Menjadi Mudah dengan SPSS 17. Jakarta: Gramedia.

Prihadi, S. (2004). Kinerja, Aspek Pengukuran. Jakarta: PT. Gramedia Pustaka.

Rivai, V. (2004). Manajemen Sumber Daya Manusia untuk Perusahaan Dari Teori ke Praktek. Jakarta: PT Raja Grafindo Perkasa. 
Rivai, V. (2009). Manajemen Sumber Daya Manusia untuk perusahaan. Jakarta: Raja Grafindo Persada.

Ruky, A. S. (2006). Sistem Manajemen Kinerja. Jakarta: PT. Gramedia. Pustaka utama.

Santoso, S. (2002a). Konsep dan Aplikasi dengan SPSS. Jakarta: PT. Elex Media Komputindo

Santoso, S. (2002b). SPSS Statistik Parametrik. Jakarta: Penerbit PT Elex Media Komputindo

Sastrohadiwiryo, B. S. (2002). Manajemen Tenaga Kerja Indonesia. Jakarta: Bumi Aksara.

Sedarmayanti. (2004). Good Governance (Kepemerintahan Yang Baik). Bagian Kedua, Bandung: CV. Mandar Maju.

Sekaran, U. (2003). Research Methods for Business: A Skill Building Approach (2nd ed.). New York: John Wiley and Son.

Sinambela, L. P. (2006). Reformasi Pelayanan Publik (Teori, Kebijakan, dan Implementasi). Jakarta: Bumi Aksara.

Sinambela, P. L. D. (2011). Reformasi Pelayanan Publik: Teori, Kebijakan dan Implemetasi. Jakarta: Bumi Aksara.

Singodimedjo, M. (2002). Manajemen Sumber Daya Manusia. Surabaya : SMMAS.

Sondang, S. P. (2002). Kiat Meningkatkan Produktivitas Kerja. Jakarta : Rineka. Cipta.

Suarny, L. (2003). Kepuasan kerja. Studi korelasional antara budaya organisasi dan disiplin kerja dengan kepuasan kerja pegawai Pusat Pengembangan Koleksi dan Pengolahan Bahan Pustaka Perpustakaan Nasional RI. TESIS. Jakarta: program Pascasarjana UHAMKA.

Suryabrata, S. (1992). Metodologi Penelitian. Jakarta: CV. Rajawali.

Sutrisno, E. (2011). Manajemen Sumber Daya Manusia. Jakarta: Prenada Media. Group

The Liang Gie. (1997). Pengantar filsafat Ilmu. Edisi kedua Yogyakarta: Liberty.

Tohardi, A. (2002). Pemahaman Praktis Manajemen Sumber Daya Manusia Universitas Tanjung Pura. Bandung: Mandar Maju.

Tu'u, T. (2004). Peran Disipiln pada perilaku dan prestasi Siswa. Jakarta: Gramedia widiasarana.

Undang-undang Republik Indonesia No. 13 Tahun 2003 Tentang Ketenagakerjaan.

Wibowo. (2007). Manajemen Kinerja. Jakarta: PT. RajaGrafindo Persada.

Widodo, J. (2001). Good Governance Telaah Dari Dimensi Akuntabilitas, Kontrol Birokrasi Pada Era Desentralisasi Dan Otonomi Daerah. Surabaya: Insan Cendekia.

\section{Copyrights}

Copyright for this article is retained by the author(s), with first publication rights granted to the journal.

This is an open-access article distributed under the terms and conditions of the Creative Commons Attribution license (http://creativecommons.org/licenses/by/3.0/). 